Przegląd Badań Edukacyjnych Educational Studies Review

ISSN 1895-4308

nr $20(1 / 2015)$, s. 19-42

ORYGINALNE ARTYKUŁY BADAWCZE

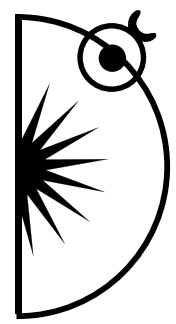

Violetta Kopińska

Uniwersytet Mikołaja Kopernika w Toruniu, e-mail: Violetta.Kopinska@umk.pl

\title{
Koncepcja / rozumienie prawa w dyskursach podręczników do wiedzy o społeczeństwie dla szkół ponadgimnazjalnych
}

DOI: http://dx.doi.org/10.12775/PBE.2015.034

\section{The Concept of Law in Discourses Found in Secondary School Textbooks for Civic Education}

\begin{abstract}
:
The aim of this paper is to diagnose the area of legal education in secondary schools. This involves the identification of dominant discourse regimes regarding the concept of law. On the one hand, the dominant discourses construct a defined framework for understanding law, while on the other, they are an expression of power, allowing one to see what is really important and desirable.

Searching for the answer to the research question: "What understanding / conception of law results from the core curriculum and textbooks for civic education?", critical discourse analysis on the basis of textbooks for civic education (fourth stage of education - upper secondary school, basic level) and the core curriculum in this area was performed. Based on the research, it has been identified as an incomplete and selective reconstruction of the concept of law and the image of the natural and positive law has been recognized as distorted. As the analysis is preliminary, it does not include all textbooks available. The results, however, are interesting because they indicate a clear valuation of the presented concepts and the dominance of positivist perspective in law understanding. This situation is in contradiction with declarations regarding the objectives of civic education and also reproduces and perpetuates dysfunctional elements of contemporary law and legal culture.
\end{abstract}

Key words: civic education, legal education, critical discourse analysis, textbooks, core curriculum, secondary school 


\section{Wprowadzenie}

Współczesny system aksjonormatywny charakteryzuje się ogromną różnorodnością, wewnętrznymi niespójnościami i sprzecznościami (Sztompka, 2012, s. 333). Wynika to $z$ określonych tendencji historycznych w rozwoju społeczeństw, do których Sztompka zalicza: coraz większe komplikowanie się i różnicowanie wzorów i reguł społecznych, przejście od izolacji kultur do konglomeratu treści pochodzących z różnych kultur, coraz większą dynamikę zmian społecznych (Sztompka, 2012, s. 332-333). Prawo stanowi jeden z podsystemów funkcjonujących w ramach systemu aksjonormatywnego (Sztompka, 2012, s. 327). Nie dziwi zatem fakt, że owe niespójności i sprzeczności dotyczą także tego obszaru.

Współczesne prawo, a ujmując to szerzej - kultura prawna (stanowiąca część kultury normatywnej), wykazuje wiele elementów dysfunkcjonalnych. Niestabilność prawa wynikająca z inkluzji politycznej ${ }^{1}$, traktowanie prawa jako najskuteczniejszego narzędzia dokonywania zmian (Kojder, 1995, s. 254), dominacja formalnych aspektów stosowania prawa nad kwestiami merytorycznymi i celowościowymi (Szubert, 1983, s. 583), nadmiar regulacji prawnych, niejasności w zakresie identyfikacji celów, którym służą poszczególne regulacje prawne (Szubert, 1983, s. 584) - to tylko niektóre, ale wyraźnie identyfikowalne symptomy. Sytuacja ta nie ma charakteru lokalnego. Różnorodne próby diagnozy specyficznych elementów współczesnej kultury prawnej odnajdujemy m.in. u Jürgena Habermasa, który wskazuje na zjawisko jurydyzacji i „kolonizacji świata" (Habermas, 2002, s. 439, 640), Lawrence'a M. Friedmana, podkreślającego rozdźwięk między indywidualizmem a legalizmem, rozumianym jako eksplozja prawa (Friedman, 1993, s. 16, 209-210), Piotra Sztompki, wskazującego na kryzys zaufania (Sztompka 2006, s. 277-286), Wojciecha Lamentowicza odwołującego się do hipotezy destrukcji normatywności (Lamentowicz, 1988, s. 269) czy Clifforda Geertza akcentującego problematykę funkcjonowania prawa pozbawionego pewników, które legły u jego podstaw (Geertz, 2005, s. 213-215). $\mathrm{Na}$ gruncie polskim natomiast należałoby zwrócić uwagę na te cechy, które są skutkiem postkomunistycznej transformacji ustrojowej. Wpisują się one w tą for-

${ }^{1}$ Inkluzja polityczna oznacza podporządkowanie prawa systemowi politycznemu. Według Luhmanna polityczna inkluzja oznacza wzrastające uzależnienie społeczeństwa od systemu politycznego, a także połączony z tym wzrost wymagań społecznych kierowanych pod adresem systemu - N. Luhmann (1981), Politische Theorie im Wohlfahrtsstaat, München, Wien, s. 25 i n. (za: Skąpska, 1988, s. 40). 
mę sprzeczności w obrębie systemu aksjonormatywnego, którą określamy jako dysonans kulturowy (Sztompka, 2012, s. 336-337). Adam Czarnota nazywa to zjawisko hybrydowością polskiego systemu prawnego, co oznacza funkcjonowanie instytucji typowych dla zachodnich demokracji, jednakże niedziałających według demokratycznych zasad (Czarnota, 2006, s. 18-21). Inną cechą wskazywaną przez Czarnotę jest karykaturalność zasady demokratycznego państwa prawa, zredukowanej do koncepcji legalności i rządów tekstu prawnego, mającej wymiar formalny i pozytywistyczny (Czarnota, 2006, s. 24-25).

W świetle powyższego, punktem zainteresowania staje się szkolna edukacja prawna, będąca ogromną siłą o charakterze reprodukcyjnym, ale z drugiej strony - stanowiąca również potencjał emancypacyjny. Mimo że napięcie między reprodukcją a emancypacją jest doskonale identyfikowalne w edukacji, wzrasta ono jeszcze bardziej, gdy obszarem odniesienia staje się edukacja prawna. Można przypuszczać, że funkcjonowanie edukacji prawnej w państwie, w którym dominuje pozytywistyczny paradygmat w myśleniu o prawie ${ }^{2}$ (Czarnota, 2006, s. 23; Kopińska, 2012), skutkuje formalizmem, transmisją wiedzy w edukacji, pozostawiając wiele ,do życzenia” w zakresie funkcji emancypacyjno-krytycznej. Czy prawo możemy poddawać krytycznej analizie i ocenie? Co z tego wyniknie? Odpowiedź twierdząca na pierwsze pytanie może rodzić obawę przed anarchią, przestępczością, brakiem poszanowania norm prawnych, co sprzeciwia się idei prawa jako takiej. To stereotypowy schemat myślenia, ale jednocześnie taki, którego możemy się spodziewać, ponieważ ma „wartość” populistyczną. W uproszczonym rozumieniu, krytyczna ocena prawa nie leży w interesie państwa, a obawa przed reprodukcją elementów dysfunkcjonalnych w prawie nie stanowi - niestety - wystarczającego powodu do rozwijania kompetencji krytycznych w tym obszarze. Warto też dodać, że emancypacja w zakresie edukacji prawnej oznaczałaby w konsekwencji zwiększenie stopnia zaawansowania partycypacji publicznej w procesach tworzenia, zmieniania i rozwijania prawa, czyli zastosowania rozwiązań, metod, technik wpisujących się w model współpracy na zasadzie partnerstwa i upodmiotowienia (Spektrum Partycypacji Publicznej wg International Association for Public Participation).

${ }^{2}$ Pozytywizm prawniczy wskazuje, że prawem jest tylko prawo pozytywne, czyli pochodzące od suwerennej władzy, eksponuje formalną stronę prawa, przymus państwowy oraz niebagatelne znaczenie nadaje treści i formie prawa. Trudno w tym miejscu opisać ten nurt szerzej, uwzględniając jego wewnętrzne zróżnicowanie. Więcej na ten temat: np. R. Tokarczyk (2009), Filozofia prawa, Warszawa: Wydawnictwo Lexis Nexis, Warszawa; B. Dupret (2010), Prawo w naukach spolecznych, Warszawa: Oficyna Naukowa; L. Morawski (2003), Pozytywizm „twardy”, pozytywizm , miękki” i pozytywizm martwy, „Ius et Lex” nr 2. 
To jednak w rezultacie wymagałoby od organów stanowiących prawo na różnych poziomach i szczeblach rezygnacji z części władzy.

Jednym z obszarów, w ramach którego realizowana jest szkolna edukacja prawna jest przedmiot wiedza o społeczeństwie. Należy przy tym podkreślić, że nie jest to ani najważniejszy, ani jedyny obszar takiej edukacji, ale taki, który doczekał się formalnej oprawy w postaci oficjalnych, tzn. rządowych dokumentów (podstawy programowe) oraz podręczników szkolnych (napisanych w oparciu o te dokumenty i zatwierdzonych do użytku szkolnego przez ministra właściwego do spraw oświaty). Warto w tym miejscu dodać, że wiedza o społeczeństwie jako przedmiot szkolny realizowany na III i IV etapie edukacyjnym została zaprojektowana w celu rozwijania kompetencji obywatelskich uczniów i uczennic. Edukacja prawna jest zatem istotną, ale nie jedyną częścią tego przedmiotu.

Koncepcja, która leży u podstaw edukacji obywatelskiej, opiera się na partycypacji i aktywności społecznej. Podkreślają to zarówno podstawy programowe jak i stanowisko Rady Europy. Gerta Biesta, dokonując analizy idei aktywnego obywatelstwa w kontekście polityki europejskiej, wskazuje na jej trzy charakterystyczne cechy: indywidualizm (większa koncentracja na działalności i odpowiedzialności jednostek niż zbiorowości czy państwa), konsensualizm (oparcie o konsensualną a nie konfliktową koncepcję demokracji), funkcjonalizm (Biesta, 2009, s. 149). To właśnie w kontekście funkcjonalizmu idei aktywnego obywatelstwa (różnicowanie rodzajów aktywności, którą jednostki powinny podejmować $\mathrm{w}$ celu reprodukcji określonego porządku socjopolitycznego), Biesta przypomina o specyficznej politycznej historii tej idei, zwłaszcza w kontekście angloamerykańskim.

Idea aktywnego obywatelstwa zarysowała się mocno w wyniku thatcheryzmu i reaganizmu w „odpowiedzi” na próżnię, która powstała w wyniku zburzenia regulacji państwa opiekuńczego. W tym kontekście aktywny obywatel był pierwsza i główną osobą, która poprzez zaangażowanie w lokalną społeczność, miałaby dostarczać „usług”, które nie są dłużej możliwe do spełniania przez system państwa opiekuńczego. To wskazuje, że w idei aktywnego obywatela nie chodzi tylko o legitymizację demokratycznych rządów. Jest ona natomiast ściśle powiązana z neoliberalną wizją dobrego społeczeństwa, w której indywidualne działania są postrzegane jako główne „rozwiązanie” problemów zbiorowych (Biesta, 2009, s. 150)³.

${ }^{3}$ Więcej na temat aktywności obywatelskiej w kontekście neoliberalizmu zob. Hildebrandt-Wypych, 2013, s. 63-67. 
Uzasadnienie dla partycypacji i aktywności społecznej w ramach tzw. podmiotowego modelu edukacji obywatelskiej (Biesta, 2009, s. 153-154) jest zgoła inne. Chodzi tu o wsparcie i promocję politycznego działania, sprawstwa politycznego (Biesta, 2009), o bardziej krytyczne i polityczne formy obywatelstwa. Jeżeli edukacja oprócz funkcji rekonstrukcyjnej i adaptacyjnej ma pełnić również funkcję emancypacyjną (Kwieciński, 1995, s. 21), to w odniesieniu do edukacji obywatelskiej oznacza to przygotowanie do krytycznej oceny funkcjonujących sił społecznych, politycznych, ekonomicznych, do zakwestionowania ich (Giroux, 1983, s. 182) oraz do uczestnictwa w zmianie otoczenia na lepsze (Kwieciński, 1995, s. 21). Poza tym należy zauważyć, że aktywność podmiotu jest istotnym elementem procesu emancypacji (Czerepaniak-Walczak, 1994, s. 141-159) pod warunkiem, że naturalną implikacją będzie tu zwiększenie stopnia zaawansowania faktycznej partycypacji publicznej. I tu napotykamy, jak wspominałam wcześniej, na zasadniczy problem. Postulat aktywności i partycypacji społecznej nie budzi kontrowersji w odniesieniu do edukacji obywatelskiej in genere (choć powody, dla których obywatele i obywatelki mają być aktywni są różne, o czym wspominałam wyżej). W zakresie edukacji prawnej dekomponuje jednak jej uproszczony, schematyczny, konformistyczny i deterministyczny obraz. Jeżeli prawo jest po to, żeby go przestrzegać i szanować, jeżeli przyjmujemy, że jest czymś, co jest nam dane „z góry”, stanowi „rozkaz", który należy wykonać, to aktywność i partycypacja społeczna w procesie tworzenia, zmieniania i rozwijania prawa nie jest ani potrzebna, ani konieczna. Konsekwencją takiego wniosku może być koncentracja na kompetencjach adaptacyjnych w zakresie edukacji prawnej oraz eksponowanie określonej koncepcji prawa.

Celem tego artykułu jest zatem analiza wycinka szkolnej edukacji prawnej. Spodziewam się przy tym dominacji dyskursów utrwalających, wykorzystujących strategie wartościujące oraz wykluczających „niewygodne” perspektywy prawa.

\section{Uwagi metodologiczne}

Pytanie badawcze, które zostało skonstruowane w ramach niniejszego artykułu, brzmi: Jakie rozumienie/jaka koncepcja prawa wynika z podstawy programowej oraz podręczników do wiedzy o społeczeństwie? Odpowiedzi na to pytanie będę poszukiwać za pomocą krytycznej analizy dyskursów podręczników do wiedzy o społeczeństwie dla IV etapu edukacyjnego na poziomie podstawowym oraz podstaw programowych w tym zakresie. 
Przyjmuję tu rozumienie dyskursu za Martinem Reisiglem, który wskazuje na dyskursy jako wieloperspektywiczne semiotyczne wiązki praktyk społecznych składających się z wzajemnie powiazanych równoczesnych i sekwencyjnych działań językowych oraz innych dziatań semiotycznych, które konstytuuja rzeczywistość spolecznq i sq przez nie konstytuowane (Reisigl, 2010, s. 36).

Według Theo van Leeuwena dyskursy są zasobami dla reprezentacji, wiedzą o różnych aspektach rzeczywistości, która jest wykorzystywana w momencie, gdy określony aspekt rzeczywistości ma być reprezentowany (Van Leeuwen, 2005, s. 95). Nie oznacza to, że dyskursy w sposób całkowity determinują to, co możemy powiedzieć o tej rzeczywistości, ale stanowią istotną ramę dla nadawania jej sensu (Van Leeuwen, 2005). Dyskursy przyczyniają się do kształtowania tożsamości i działań człowieka (Luke 1997, s. 5), a działając przez określone pojęcia, konwencje, kategorie, konstruują określoną rzeczywistość, która jest postrzegana jako prawdziwa lub fałszywa, słuszna lub nie (Dahlberg i in., 2013, s. 82). Treści kształcenia natomiast są nie tylko elementem socjalizacji szkolnej, ale mogą również dawać odpowiedź na pytanie: „,co dane społeczeństwo $\mathrm{w}$ określonym momencie uważa za istotne [...], w jaką wiedzę, umiejętności i $[\ldots]$ postawy $[\ldots]$ chciałoby $[. .$.$] [członków społeczeń-$ stwa - V.K.] wyposażyć?"' (Zamojska, 2010, s. 127).

Zdaniem Leeuwena dowodem na istnienie danego dyskursu jest tekst (nie tylko pisany), a w szczególności podobieństwo, które wynika z różnych tekstów, a dotyczy tego samego aspektu rzeczywistości (Van Leeuwen, 2005). Zgodnie z powyższym, w przypadku niniejszego artykułu dyskurs dotyczy edukacji prawnej, a jego rekonstrukcja dokonana zostaje na podstawie tekstów, które należą do dwóch zasadniczo odmiennych gatunków. Podstawy programowe do przedmiotu wiedza o społeczeństwie stanowią fragment rozporządzenia Ministra Edukacji Narodowej. Jest to więc gatunek prawny, który posiada swoje cechy charakterystyczne, m.in. takie jak: tryb oznajmujący, brak argumentacji, brak przeciwstawnych stanowisk. Tekst ten został wybrany z dwóch powodów. Po pierwsze - jest przykładem realizacji dyskursu na poziomie państwowym. Wskazuje na efekty edukacji, w szczególności - edukacji obywatelskiej, w tym - edukacji prawnej, które są lub nie są aktualnie eksponowane przez państwo. Rodzaj aktu prawnego, za pomocą którego ustanawiane są podstawy programowe też ma tu znaczenie. Rozporządzenie jest aktem prawnym powszechnie obowiązującym, ale jednocześnie mającym niższą moc prawną niż Konstytucja, ustawy czy ratyfikowane umowy międzynarodowe. Konsekwencją takiego stanu rzeczy i obowiązywania reguły hierarchicznej w Polsce jest to, że podstawy programowe uchwalone $\mathrm{w}$ formie rozporządzenia muszą być zgodne $\mathrm{z}$ ak- 
tami prawnymi mającymi wyższą moc prawną. To w rezultacie oznacza, że należy zdawać sobie sprawę z ograniczeń co do wniosków wynikających bezpośrednio z podstaw programowych. Wszak stanowią one zaledwie jeden element całej sieci powiązanych ze sobą aktów prawnych, które dotyczą edukacji czy to w wymiarze formalno-organizacyjnym czy merytorycznym. Warto przy tym zauważyć swoisty paradoks - badając dyskurs dotyczący edukacji prawnej, sięga się do gatunków, które same są regulacjami prawnymi i to zależnymi od innych przepisów. Jednocześnie istotne jest to, że z samego faktu regulowania prawnego określonych aspektów edukacji, w tym edukacji prawnej, wynika wiedza na temat rzeczywistości edukacyjnej, która z kolei konstytuowana jest m.in. za pomocą tych regulacji.

Należy również pamiętać, że forma rozporządzenia oznacza, że jest to akt prawny wydawany przez ministra, w tym przypadku - ministra właściwego do spraw oświaty (obecnie Ministra Edukacji Narodowej), a zatem nie jest uchwalany przez Sejm i Senat. To z kolei predestynuje go do tego, by określić go w kategoriach dokumentu ,rządowego”. Po drugie - to właśnie na podstawie tego tekstu tworzone są (pod względem merytorycznym) podręczniki szkolne, które stanowią drugi spośród gatunków wybranych do analizy. Warto przy tym zauważyć, że podręczniki szkolne, które ,zostały dopuszczone do użytku szkolnego", muszą być zgodne z podstawami programowymi, ale mogą oczywiście poza nie wykraczać. Interesujący jest także sposób realizacji określonych wskazań zawartych w podstawach programowych przez teksty podręczników. Podstawy programowe są zatem zarówno tekstem, który pozwala na rekonstrukcję dyskursu dotyczącego edukacji prawnej, jak i kontekstem dla analizy dyskursu rekonstruowanego na podstawie podręczników szkolnych.

Badana próba obejmuje zatem:

- Rozporządzenie Ministra Edukacji Narodowej z dnia 27.08.2012 roku w sprawie podstawy programowej wychowania przedszkolnego oraz kształcenia ogólnego w poszczególnych typach szkół, Dz. U. z 2012, poz. 997, załącznik nr $4 \mathrm{w}$ zakresie dotyczącym podstawy programowej przedmiotu wiedza o społeczeństwie dla IV etapu edukacyjnego na poziomie podstawowym oraz

- cztery (spośród siedmiu) podręczników do przedmiotu wiedza o społeczeństwie dla IV etapu edukacyjnego na poziomie podstawowym (oznaczonych [1P] - [4P] niezależnie od podanej niżej kolejności ich wymienienia):

- Zbigniew Smutek, Jan Maleska, Wiedza o społeczeństwie. Podręcznik dla szkót ponadgimnazjalnych. Zakres Podstawowy, Operon 2013; 
- Arkadiusz Janicki, W centrum uwagi. Podręcznik do wiedzy o spoteczeństwie dla szkól ponadgimnazjalnych. Zakres podstawowy, Wydawnictwo Nowa Era, Warszawa 2012;

- Katarzyna Fic, Maciej Fic, Lech Krzyżanowski, Wiedza o społeczeństwie. Podręcznik dla szkót ponadgimnazjalnych. Zakres podstawowy, SOP Oświatowiec Toruń Sp. z o. o. 2012;

- Iwona Walendziak, Mikołaj Walczyk, Wiedza o społeczeństwie dla szkót ponadgimnazjalnych, Podręcznik z ćwiczeniami, Zakres podstawowy, Wydawnictwo Edukacyjne Zofii Dobkowskiej „Żak”, Warszawa 2012.

Przedstawione w niniejszym artykule analizy mają charakter pilotażowy, stanowiąc określony etap badań dotyczących szkolnej edukacji prawnej. Z tego też powodu badana próba nie obejmuje wszystkich podręczników do wiedzy o społeczeństwie, a analizy ograniczają się do jednego wybranego kryterium - koncepcji/rozumienia prawa. Przyjmuję przy tym taką definicję koncepcji/ rozumienia prawa, zgodnie z którą jest to zbiór poglądów na prawo, jego istotę, funkcjonowanie, często związany z określonymi nurtami w rozwoju myśli naukowej, zwłaszcza w zakresie nauk społecznych.

Analizy dyskursów wskazanych wyżej źródeł wtórnych dokonano w oparciu o wybrane strategie dyskursywne (rozumiane jako mniej lub bardziej właściwy i intencjonalny plan działań zastosowanych po to, by osiagnaḉ dany cel):

a) Strategię nominalizacji, predykacji, argumentacji, wzmacniania/tonowania;

b) Strategię konstruktywną, utrwalającą i usprawiedliwiająca, transformacyjna, demontującą i destruktywną (Reisigl, Wodak, 2001; Reisigl, 2010; Reisigl, 2011, s. 150-183).

Pierwsza grupa strategii znajduje swoje zastosowanie w dyskursach dyskryminacyjnych, ponieważ pozwala na identyfikację takich cech dyskursów, które budują pozytywny wizerunek jednych i negatywny innych aktorów społecznych. Przeprowadzona analiza pokazała jednak, że wskazana grupa strategii jest również adekwatna do podejmowanego tu zagadnienia - koncepcji/ rozumienia prawa. Przyjęcie tej grupy strategii jako kategorii analizy doprowadziło do skonstruowania następujących pytań szczegółowych:

1. W jaki sposób konstruowany jest wizerunek prawa? W oparciu o jakie koncepcje (nominalizacja)?

2. Czy i w jaki sposób wartościowane są owe koncepcje? Jakie cechy pozytywne/negatywne przypisywane są prawu ujmowanemu w ramach określonej jego koncepcji (orzekanie - predykacja)? 
3. Za pomocą jakich argumentów i schematów argumentacyjnych próbuje się uzasadnić ewentualne przykłady orzekania (argumentacja)?

4. Czy w analizowanych wypowiedziach obecne są wzmocnienia lub tonowanie (wzmacnianie/tonowanie)?

Druga grupa wskazanych wyżej strategii (punkt b) jest szczególnie użyteczna dla określenia sposobu konstruowania tożsamości narodowych (De Cillia, Reisigl, Wodak, 1999). W przypadku podejmowanych tu analiz przyjęto następującą interpretację:

- strategia konstruktywna służy konstruowaniu określonego wizerunku/ rozumienia prawa jako elementu tożsamości narodowej;

- strategia utrwalająca i usprawiedliwiająca zmierza do reprodukcji dominującej/dominujących koncepcji prawa i usprawiedliwia określone rozumienie przez np. legitymizację odwołującą się do idei, procedury lub standardu;

- strategia transformacyjna - jej celem jest przekształcanie różnych relatywnie ustabilizowanych aspektów tożsamości (w tym również rozumienia prawa) $\mathrm{w}$ inne;

- strategia demontująca i destrukcyjna używana jest w celu demitologizacji i demontażu istniejących elementów tożsamości (De Cillia, Reisigl, Wodak, 1999, s. 160-161).

Analiza dyskursu zostanie dodatkowo poszerzona o wybrane kategorie stworzone przez Theo van Leeuwena (Van Leeuwen 1996, s. 32-70, Van Leeuwen, 2005); chodzi tu zwłaszcza o:

- ekskluzję oznaczającą wyłączanie określonych koncepcji prawa za pomocą supresji (radykalne wyłączenie bez żadnych odniesień w tekście) lub backgroundingu (o tym, że istnieją określone koncepcje możemy się domyślać na podstawie różnych odniesień w różnych miejscach tekstu);

- asocjację i dysocjację - oznaczająca, że określone koncepcje są ze sobą zestawiane tylko po to, by zrealizować konkretny cel wypowiedzi (asocjacja), po osiagnnięciu tego celu, w innych okolicznościach nie wspomina się o nich w tym konkretnym zestawieniu, mimo że mogłoby to być uzasadnione (dysocjacja);

- indeterminację i determinację - oznaczająca, że określone koncepcje prawa są oznaczone, nazwane (determinacja), a inne mimo że są wspominane, to jednak nie są wyspecyfikowane (indeterminacja) (Leeuwen, 2005). 


\section{Podstawa programowa wobec zagadnień prawnych}

W pierwszej kolejności należy stwierdzić, że podstawa programowa przedmiotu wiedza o społeczeństwie dla IV etapu edukacyjnego (zakres podstawowy) w połowie odwołuje się do komponentu wiedzy (w tym także do wiedzy na temat prawa). Obejmuje on następujące elementy: Znajomość zasad i procedur demokracji (punkt IV), Znajomość podstaw ustroju Rzeczypospolitej (punkt V), Znajomość praw człowieka i sposobów jego ochrony (punkt VI). W ramach opisu pozostałych wymagań można odnaleźć określone fragmenty stwarzające dla uczniów możliwości rozwoju kompetencji emancypacyjno-krytycznych, np.: wyraża wlasne zdanie $w$ wybranych sprawach na różnych forach publicznych i uzasadnia je; jest otwarty na odmienne poglady (Załącznik nr 4 do Rozporządzenia Ministra Edukacji Narodowej z dnia 27 sierpnia 2012 roku w sprawie podstawy programowej wychowania przedszkolnego oraz kształcenia ogólnego w poszczególnych typach szkół, Dz. U. z 2012, poz. 997). Należy jednak zwrócić uwagę, że tam, gdzie tekst odnosi się wprost do prawa, dyskurs posługuje się strategią utrwalająca, np. sprawnie korzysta z procedur i możliwości, jakie stwarzaja obywatelom instytucje życia publicznego (Załącznik nr 4 do Rozporządzenia Ministra Edukacji Narodowej z dnia 27 sierpnia 2012 roku w sprawie podstawy programowej wychowania przedszkolnego oraz kształcenia ogólnego w poszczególnych typach szkół, Dz. U. z 2012, poz. 997). Warto dodać, że powyższy cytat pochodzi z wymagania ogólnego określonego jako współdziałanie w sprawach publicznych. Trudno powiedzieć, by opis tego wymagania korespondował z koncepcją aktywności społecznej rozumianą w kategoriach potencjału emancypacyjnego podmiotu. Nie ma tu także odniesien, do - podkreślanego także $\mathrm{w}$ ramach obywatelskich kompetencji kluczowych w procesie uczenia się przez całe życie - uczestnictwa w procesach podejmowania decyzji (Załącznik do Zalecenia Parlamentu Europejskiego i Rady Unii Europejskiej nr 2006/962/WE). Powyższy wniosek potwierdza analiza wymagań szczegółowych. Żaden z analizowanych punktów nie dotyczy kwestii związanych z partycypacją uczniów w procesie podejmowania decyzji. Aktywne obywatelstwo nawiązuje tu raczej do funkcjonalistycznego ujmowania tej idei, wskazywanego przez Gerta Biestę.

Tylko jedno z wymagań szczegółowych $\mathrm{w}$ analizowanej podstawie programowej odnosi się wprost do rozumienia prawa. Wymaganie to zostało sformułowane następująco: Uczeń [...] wyjaśnia, co to jest prawo i czym się różniq normy prawne od norm religijnych, moralnych i obyczajowych (Załącznik $\mathrm{nr} 4$ do Rozporządzenia Ministra Edukacji Narodowej z dnia 27 sierpnia 2012 roku 
w sprawie podstawy programowej wychowania przedszkolnego oraz kształcenia ogólnego w poszczególnych typach szkół, Dz. U. z 2012, poz. 997). Co prawda wymaganie to nie wskazuje żadnej koncepcji prawa, ale to właśnie próba rekonstrukcji definicji prawa uzasadnia potrzebę uwzględnienia różnych jego koncepcji, ujęć. $Z$ drugiej strony, w ramach tego wymagania nie wskazano wprost tego, że uczeń zapoznaje się z różnymi koncepcjami/perspektywami rozumienia prawa, co oznacza, że program nauczania oraz podręcznik opierający się na tej podstawie może poprzestać na jednostronnej definicji, a to de facto skutkuje wykluczeniem/pomniejszeniem roli innych koncepcji przez zastosowanie strategii ekskluzji.

\section{Koncepcja(e) prawa w dyskursach podręcznikowych}

Powyższe uwagi znajdują swoje potwierdzenie w analizie dyskursów podręczników do wiedzy o społeczeństwie. Niestety ewentualny potencjał wskazanego wyżej wymagania szczegółowego nie jest wykorzystany. Mamy tu bowiem do czynienia $\mathrm{z}$ wykluczeniem wielu koncepcji prawa. Nie chodzi tylko o fakt braku ujęć prawa charakterystycznych dla współczesnych doktryn prawnych. Dyskursy podręcznikowe nie wykraczają poza dychotomię prawo pozytywneprawo naturalne. Nie ma tu mowy o realizmie prawniczym, nie mówiąc już o innych koncepcjach prawa, np. socjologicznych, psychologicznych, ekonomicznych. Zastosowano w tym zakresie strategię ekskluzji za pomocą supresji. Rekonstrukcja w tym zakresie jest zatem niepełna i selektywna.

Jeśli chodzi natomiast o koncepcję prawa naturalnego, również ma ona charakter niepełny i zniekształcony. Niepełny dlatego, że w żadnym z analizowanych podręczników nie wspomina się o prawie natury o zmiennej treści. W ten sposób pomija się istotny nurt w rozwoju myśli prawa naturalnego, zapoczątkowany przez Immanuela Kanta, a kontynuowany np. przez Rudolfa Stammlera (Chojnicka, Olszewski, 2004, s. 356; Tokarczyk, 2009, s. 115, 119-120). Zniekształcenie koncepcji prawa naturalnego polega na tym, że dyskurs wyraźnie eksponuje jakąś określoną doktrynę w ramach prawa naturalnego i to na tej właśnie podstawie konstruuje wizerunek tego prawa.

Przyjrzyjmy się przykładowi, który tego dotyczy:

\section{Przykład 1}

Wedtug jednych koncepcji prawo naturalne wywodzi się bezpośrednio z natury pojmowanej jako środowisko przyrodnicze. 
Nauka Kościola katolickiego prawo naturalne utożsamia z prawami boskimi $i$ nie wiaże go z ustanowieniem czy uznaniem przez władzę, lecz wywodzi je z natury cztowieka, obdarzonego przez Boga rozumem i wolnq wolq. Normy prawa naturalnego, niezależne od woli władzy, sa przez to trwalsze od prawa pozytywnego, a niektóre jego reguly sq wręcz niezmienne. W minionych stuleciach $w$ różnych formach ustrojowych państwa, prawo tworzone przez władców niezgodnie z prawem naturalnym (boskim) nierzadko powodowało konflikty w państwie, przyczyniajac się do buntu przeciw władcy. Idea prawa naturalnego miała decydujacy wplyw na kształtowanie się koncepcji praw człowieka. Wspótcześnie jest ono traktowane jako wzór, na którym powinno się opierać prawo stanowione przez ludzi. Koncepcja prawa naturalnego jako nadrzędnego wobec prawa państwowego jest konsekwencja odwiecznego pragnienia, aby prawo ludzkie byto dobre, sprawiedliwe, a nie konstruowane dla doraźnych interesów osób sprawujacych władzę. Idea prawa naturalnego pozwolita między innymi na osqdzenie zbrodniarzy wojennych w procesach norymberskim i tokijskim po zakończeniu II wojny światowej.[1P]

Choć pierwsze zdanie tego tekstu sygnalizuje inną niż Bóg podstawę prawa natury, to należy zwrócić uwagę, że mowa jest tu o jakichś bliżej nieokreślonych ,jednych" koncepcjach (indeterminacja). Dalej tekst odwołuje się już do prawa boskiego, a nawet konkretnego wyznania, podkreślając w dalszej części, przez zastosowanie nawiasu, że prawo naturalne utożsamiane jest z prawem boskim (determinacja). Nawet tam, gdzie tekst odnosi się do natury człowieka, jego rozumu i wolnej woli, to podkreśla, że są to atrybuty, którymi obdarza Bóg. Dyskurs konstruuje zatem określony wizerunek prawa naturalnego. Zastosowano tu także strategię predykacji, wartościując prawo naturalne (tu: boskie) i prawo pozytywne, które - z kolei - przedstawiane jest w negatywnym świetle. Do ekspozycji określonego rozumienia prawa naturalnego zastosowano strategię legitymizacji przez standaryzację (odwołanie się do dominującego w Polsce wyznania) oraz strategię wzmocnienia przez odwołanie się do zbrodni nazistowskich.

Warto także przyjrzeć się innemu fragmentowi tego samego podręcznika.

\section{Przykład 2}

\section{Prawo naturalne a stanowione}

Normy prawne moga być tworzone i zmieniane przez ustawodawce dość szybko $w$ celu dostosowania ich do zachodzacych w państwie procesów po- 
litycznych i przeobrażeń spolecznych. W porównaniu z nimi normy moralne $i$ obyczajowe sq względnie trwałe, gdyz ksztattuja się wolniej i obowiqzuja znacznie dhuzej. Prawo obowiqzujace $w$ danym państwie, czyli ogót norm zachowania ustanowionych lub uznanych przez wtadzę państwowa $i$ zagwarantowanych przymusem - to prawo pozytywne.

Prawo naturalne jest rozumiane jako zbiór norm, które obowiqzuja cate spoleczeństwo $i$ wtadzę państwowa bez względu na to, czy sq one przez tę wtadzę ustanowione i uznawane. [1P]

Wartość prawa naturalnego jest podkreślana w opozycji do prawa pozytywnego. W rezultacie konstruowany jest wizerunek prawa pozytywnego, które jawi się jako nietrwałe, dostosowane do procesów politycznych, doraźne (przykład 1 i 2) (orzekanie). Wartościując obie koncepcje, ukryto w dwóch ostatnich zdaniach następujące presupozycje: prawo naturalne jest nie zawsze uznawane przez władzę, prawo pozytywne jest nie zawsze zgodne z prawem naturalnym, prawo pozytywne nie obowiązuje władzy.

Mimo tak przedstawionej relacji prawa pozytywnego i naturalnego, w ramach podręcznikowego podsumowania wyeksponowano prawo pozytywne (sic!), wspominając co prawda o prawie naturalnym, ale poświęcając przede wszystkim uwage formalnym aspektom prawa charakterystycznym dla jego pozytywistycznej wizji. Prawo naturalne, jak wskazuje przykład 1, pozostaje zatem w sferze pragnień.

Podobne wnioski wynikają z analizy dyskursu w kolejnym $\mathrm{z}$ analizowanych podręczników [2P].

Tu także widoczne jest swoiste „pęknięcie” między tą częścią książki, która w sposób ogólny odnosi się do prawa, a tą, która poświęcona jest prawom człowieka. Niestety nie można tego zabiegu określić w kategoriach „dwoistości” w rozumieniu tego terminu zastosowanym przez Lecha Witkowskiego (Witkowski, 2013). Tak by było, gdyby ukazywano złożoność relacji między prawem pozytywnym i naturalnym, nie oceniając jednoznacznie któregokolwiek z tych porządków, ale dyskutując czy prowokując do dyskusji na ten temat. Tymczasem dyskurs podręcznikowy na temat koncepcji prawa wydaje się „pękać”. Prawno-naturalne i pozytywistyczne ujęcia prawa ulegają asocjacji przy okazji podejmowania tematyki praw człowieka. Jednocześnie oba porządki prawne są wartościowane, a dyskurs eksponuje określone źródło pochodzenia praw natury. Zupełnie zapomina się o tym w innych obszarach tematycznych. Definicje prawa pojawiające się w ramach tematyki „Prawo i sądy”, mają charakter czysto formalny, co świadczy o przyjęciu pozytywistycznej koncep- 
cji prawa, mocno krytykowanej w tekstach dotyczących praw człowieka. To potwierdza, że relacja między prawno-naturalnym i pozytywnym porządkiem prawnym pojawia się $\mathrm{w}$ dyskursie $\mathrm{w}$ konkretnym celu, następnie zaś ulega rozpadowi (dysocjacji) i nie jest brana pod uwagę przy tworzeniu podstawowej definicji prawa.

Oto definicja prawa zawarta w rozdziale podręcznika zatytułowanym „Prawo i sądy”:

\section{Przykład 3}

[...] system norm prawnych stworzonych przez organy państwowe, którym każdy winny jest postuszeństwo [2P].

Tymczasem w rozdziale dotyczącym praw człowieka czytamy:

Przykład 4

W końcu XIX wieku w nance prawa narodziła się koncepcja pozytywizmu prawnego, która zaktadata, że prawo pochodzi każdorazowo od prawodawcy, który je ustanawia, określa jego treść i je sankcjonuje. Spowodowało to odrodzenie starego, znanego już w starożytności, konfliktu o to, które prawa sq ważniejsze: naturalne czy stanowione. Tym razem byt to spór między zwolennikami dwóch doktryn: prawa naturalnego i pozytywnego. Z pozytywistycznego punktu widzenia prawa naturalne $i$ wynikajace $z$ nich prawa czlowieka nie istnieja. Wszelkie prawa, które posiada jednostka, sq uprawnieniami zagwarantowanymi przez prawo pozytywne i moga być dowolnie cofnięte lub ograniczone. Pozytywiści prawni przekonywali, że jedynq rzeczywistościa jest realny świat, a co za tym idzie, należy bezwzględnie stuchać istniejacej władzy.

Przyjęcie takiego założenia sprzyjało totalitarnym ujęciom prawa dopuszczajacym dowolna jego treść. W ten sposób pozytywizm prawniczy wspótksztaltowat bezprawie ubrane w szaty prawa w komunistycznej Rosji czy nazistowskich Niemczech. Pozytywizm prawny utożsamiajacy ustawe z prawem byt - pisat niemiecki profesor filozofii prawa uniwersytetu w Heidelbergu Gustav Radbruch - , wspótwinny udziatu niemieckiej nauki prawa w tworzeniu stanu prawnego lat narodowego socjalizmu”.

Jednak podczas dyskusji nad odpowiedzialnościq nazistów za śmierć milionów ludzi po klęsce III Rzeszy w II wojnie światowej nastapiła rehabilitacja prawa naturalnego. To m.in. w tej debacie Gustav Radbruch przeciwstawit 
„prawo ponadustawowe” (naturalne) ,, ustawowemu bezprawiu”. Twierdzil, że przepisy prawa pozytywnego (stanowionego, lex), które sq , rażaco, w najwyższym stopniu sprzeczne" z prawem naturalnym (jus), powinny być w procesie stosowania prawa traktowane tak, jakby w ogóle nie obowiazywaty (,, prawo nieprawne nie jest prawem" - tzw. formula Radbrucha).

Dzięki powrotowi do doktryny prawa naturalnego i zastosowaniu formuly Radbrucha udało się oskarżyć $i$ skazać w procesach norymberskich i procesie tokijskim wielu zbrodniarzy wojennych za (niewystęujace dotad waktach prawa stanowionego) zbrodnie ludobójstwa i zbrodnie przeciwko ludzkości. [2P]

Warto porównać jednoznacznie negatywny wizerunek prawa pozytywnego, który konstruowany jest $\mathrm{w}$ przykładzie $4 \mathrm{z}$ bezdyskusyjnie przedstawioną definicją prawa pochodzącą z innego rozdziału (przykład 3).

Przykład 4 pokazuje zastosowanie strategii nominalizacji, połączonej z orzekaniem. Dyskurs konstruuje wartościujący, zdecydowanie negatywny wizerunek prawa pozytywnego, pozostającego w opozycji do prawa naturalnego. Argumentacja takiej oceny została przy tym wzmocniona przez odwołanie się do komunizmu i nazizmu. Wykorzystano zatem argumentum ad populum. Odwołano się również do poglądów Gustava Radbrucha, nie analizując jednak jego myśli i historii dla ukazania złożoności relacji między prawem naturalnym i pozytywnym, ale wykorzystując jego poglądy dla uprawomocnienia prezentowanego osądu.

Mimo że w podręczniku zawarto informacje odnoszące się do różnych sposobów rozumienia źródeł prawa naturalnego, dyskurs wyraźnie akcentuje deterministyczne ujęcie prawa naturalnego (przykład 5), a odwołanie się do św. Augustyna kieruje naszą uwagę na prawo boskie.

\section{Przykład 5}

System naturalnoprawny zaktada istnienie takiego prawa, które jest obiektywne oraz niezależne od woli $i$ świadomości i czlowieka (nazywanego często nadrzędnym albo absolutnym, a w niektórych okresach historii - boskim). Zawiera ono moralne pewniki, które pozwalaja człowiekowi odróżnić dobro od zła. Może on te reguly naruszyć, ale nie może ich unieważnić. Jak pisat św. Augustyn, jest to ,prawo zapisane w sercach ludzkich, którego nie może wymazać niegodziwość". Jego normy sq niezmienne, bardziej pierwotne i trwalsze niż prawo pisane, a w zwiazku z tym obowiqzuja niezależnie od prawodawstwa państwowego (prawa stanowionego). [2P] 
Analiza dyskursu kolejnego podręcznika do wiedzy o społeczeństwie [3P] doprowadza do wniosku o całkowitym braku związku między prawem naturalnym i pozytywnym.

\section{Przykład 6}

Prawo naturalne i pozytywne

Ludzie od wieków poszukuja odpowiedzi na pytanie, które prawo jest ważniejsze: naturalne czy pozytywne.

Prawo naturalne to system norm oraz wartości obowiqzujacych niezaleznie od decyzji czlowieka. Moga one pochodzić od Boga, wynikać z natury ludzkiej rozumianej jako zdolność jednostki do refleksji nad sobq i światem, a także z godności czlowieka, czyli jego wyjatkowego statusu wśród istot żywych. Prawo naturalne jest uważane za najtrwalsze, majace decydujace znaczenie $w$ razie wystapienia sprzeczności z normami stworzonymi przez człowieka. Zwolennicy tego prawa uważajaje za sprawiedliwe, powszechne i obiektywne. Nie musi ono być spisywane. Człowiek powinien dażyć do jak najpetniejszej realizacji jego nakazów w swoim życiu.

Prawo pozytywne, tworzone przez ludzi, zależy od woli ustawodawcy, dbajacego o dobro społeczności. Obowiazuje na danym terenie $i$ w określonym czasie - od ustanowienia do uchylenia lub wprowadzenia zmian. Zwolennicy koncepcji o wyższości tego rodzaju prawa twierdza, że należy respektować tylko takie normy, którym nadano formę dokumentu. [3P]

$\mathrm{Na}$ brak związku między prawem pozytywnym a naturalnym wskazuje również tabela umieszczona $\mathrm{w}$ podręczniku, która różnicuje obie koncepcje w odniesieniu do określonych kryteriów. Podział jest uproszczony i dość schematyczny i nie uwzględnia wewnątrzdoktrynalnego zróżnicowania koncepcji. Warto również dodać, że powyższe uwagi, inaczej niż w poprzednio analizowanych podręcznikach, zostały umieszczone w rozdziale pt. „Prawo”. W rozdziale dotyczącym praw człowieka nie ma natomiast bezpośrednich odwołań do prawa naturalnego, co stanowi zabieg pomniejszający jego rolę. Dyskurs posługuje się zatem strategią ekskluzji w odniesieniu do relacji między prawem naturalnym i prawem stanowionym oraz $\mathrm{w}$ odniesieniu do związku między prawami człowieka i prawem naturalnym. To zdecydowanie marginalizuje prawno-naturalne ujęcie prawa. Podstawowa definicja prawa zawarta w podręczniku (przykład 7) ma natomiast charakter formalny, rodowód pozytywistyczny, a podręcznikowe podsumowanie do analizowanego rozdziału również eksponuje formalną stronę 
prawa. Dyskurs ma tu również charakter orzekający, a jego funkcja rekonstrukcyjna jest szczególnie „kulejąca”.

\section{Przykład 7}

\section{Definicja prawa}

Jest to uporzadkowany zbiór norm postępowania powszechnie obowiazujacych na terytorium danego państwa i ustanowionych przez jego odpowiednie organy. Realizację tych norm wspiera zagrożenie użycia środków przymusu i wymierzenia kary przez państwo. [3P]

Dyskurs kolejnego podręcznika konstruuje wizerunek prawa oparty przede wszystkim na prawie pozytywnym.

\section{Przykład 8}

Dla członków społeczeństwa, zobowiqzanych do przestrzegania prawa, szczególne znaczenie maja normy prawne, czyli normy które zostaty ustanowione przez organy władzy publicznej, wyróżniajace się tym, że przestrzegane sa pod przymusem państwa - jako system nakazów, uprawnień i zakazów. [4P]

Zastosowano tu strategię orzekania, wskazując jednoznacznie, że normy prawne są najważniejsze. Nie zastosowano przy tym argumentacji. Ewentualnie można tu dopatrzyć się legitymizacji poprzez standaryzację. Dyskurs odwołuje się bowiem do zasady państwa prawa, uznawanej jako podstawowa w ramach ustroju demokratycznego. W jednym z fragmentów napisano:

\section{Przykład 9}

Być może zetknateś się już z terminem państwo prawa. Charakteryzuje on takie państwo, które rzqdzone jest przez prawo, a nie jakikolwiek autorytet, site, ideologię czy osobę. [...] W państwie prawa istnieje pierwszeństwo norm prawnych wobec wszelkich innych norm w postępowaniu organów państwa. [4P]

Podobna argumentacja została zastosowana $\mathrm{w}$ ramach dyskursu podręcznika [3P]. 


\section{Przykład 10}

Skrupulatne przestrzeganie ustalonych regut przez organy państwa odgrywa natomiast role wychowawcza $i$ motywuje obywateli do postępowania zgodnego z treściq prawa. Zasadę praworzqdności uznaja wszystkie państwa demokratyczne. [3P]

Użycie określenia „skrupulatne” przenosi akcent z merytorycznego na formalny aspekt prawa. Oprócz legitymizacji przez standaryzację odwołano się tu do wychowawczych aspektów stosowania takiej zasady.

Warto zwrócić uwagę, że zwłaszcza w przykładzie 9 mamy do czynienia $\mathrm{z}$ depersonalizacją prawa $\mathrm{w}$ tym sensie, że zostaje ono całkowicie oderwane od człowieka. Państwo rządzone jest przez prawo, a nie przez ludzi. Chyba zapomniano o tym, że jednak ktoś to prawo musi stworzyć. Taki zabieg nadaje dodatkowo prawu cechy zjawiska abstrakcyjnego i niedostępnego ludziom oraz wykluczającego człowieka jako jego twórcę.

Ekspozycja takiego wizerunku prawa $\mathrm{w}$ dyskursie analizowanego podręcznika została dodatkowo wzmocniona przez zastosowanie strategii ekskluzji. Dyskurs wyklucza jakiekolwiek inne koncepcje prawa. O prawie naturalnym wspomina się tylko raz, nie rozwijając w żaden sposób tego pojęcia (backgrounding).

Przykład 11

Prawa człowieka, ze względu na ich charakterystyczne cechy, określa się mianem praw naturalnych, ponieważ sq właściwe dla wszystkich ludzi. [4P]

\section{Podsumowanie i wnioski}

Podsumowując, analiza koncepcji/rozumienia prawa w dyskursie podstawy programowej i wskazanych podręczników do wiedzy o społeczeństwie na IV etapie edukacyjnym (zakres podstawowy) pozwala stwierdzić:

1. Podstawy programowe nie wykluczają możliwości uwzględnienia w procesie edukacji różnych koncepcji prawa, ale też nie wskazują tego wprost. W rezultacie może to wpływać na ekspozycję jednej wybranej koncepcji prawa przy jednoczesnym wykluczeniu innych.

2. Całościowe spojrzenie na podstawę programową pozwala stwierdzić, że w odniesieniu do zagadnień prawa, dyskurs posługuje się strategią utrwalająca, a nie - transformacyjną. 
Violetta Kopińska Koncepcja / rozumienie prawa w dyskursach podręczników...

3. W dyskursach wybranych podręczników identyfikowalne są:

- niepełna i selektywna rekonstrukcja koncepcji prawa, która nie wykracza poza dychotomię prawo naturalne-prawo pozytywne, konstruowanie niepełnego i zniekształconego wizerunku prawa naturalnego i pozytywnego a także

- wyraźne wartościowanie prezentowanych koncepcji prawa (strategia predykacji, wzmacnianie) oraz określonych doktryn w ramach tych koncepcji.

4. W dyskursach analizowanych podręczników mamy do czynienia z wyraźną dominacją koncepcji pozytywistycznej prawa. Charakterystyczne jest przy tym swoiste ,pęknięcie” między wizerunkiem prawa rekonstruowanym na podstawie dyskursu dotyczącego praw człowieka a tego, który odnosi się do prawa funkcjonującego w danym państwie. Powodem dla ewentualnego zaistnienia w tych dyskursach koncepcji prawa naturalnego jest podejmowanie tematyki odnoszącej się do praw człowieka. Tam jednak, gdzie konstruowane są zasadnicze definicje prawa, koncepcja wcześniej negatywnie wartościowana (pozytywistyczna, choć dyskursy nie określają jej wprost tym mianem), zostaje wyeksponowana. Może to wynikać z głębokiego zakorzenienia pozytywistycznego wizerunku prawa, z ,uwięzienia” (być może nie do końca świadomego?) w jednej perspektywie.

Jeżeli zatem dyskurs traktujemy jako „wiedzę o różnych aspektach rzeczywistości”, która stanowi istotną ramę dla nadawania sensu tej rzeczywistości, to wnioski wypływające $\mathrm{z}$ analizy dyskursów podstawy programowej i wybranych podręczników do wiedzy o społeczeństwie dla IV etapu edukacyjnego nie wychodzą naprzeciw problemom współczesnego prawa i kultury prawnej. „Uwięzienie” w ramach określonej koncepcji prawa nadaje również określony sens praktykom społecznym w zakresie tworzenia, stosowania i przestrzegania prawa. Mimo deklaracji, nie chodzi tu o partycypację publiczną - tylko o znajomość, podporządkowanie i przestrzeganie prawa.

Prawa należy przestrzegać i nie ma co do tego żadnych wątpliwości. Prawo jednak powinno być „słuszne i sprawiedliwe”. Jeżeli jednak jego jakość pozostawia wiele do życzenia, to czy rzeczywiście dyskursy obecne w ramach szkolnej edukacji prawnej powinny mieć charakter utrwalający? Czy naprawdę chodzi tu o reprodukcję takiego stanu rzeczy? Czy rzeczywiście w ramę, która w jakimś stopniu nadaje sens rzeczywistości, chcemy wpisywać wyłącznie komunikat - „przestrzegaj prawa”, zwykle dodając „,bo jak nie, to spotkają ciebie sankcje"? Jeżeli na któreś z tych pytań odpowiemy przecząco, to wyniki 
przeprowadzonej w tym artykule analizy są nieco niepokojące. Należy zwrócić uwagę, że nie tylko koncepcja/rozumienie prawa ma znaczenie dla oceny dyskursu szkolnej edukacji prawnej. Jest ona jednak ważnym elementem. Sposób, w jaki ludzie pojmują prawo, wpływa z pewnością na określone praktyki społeczne. Warto by było zatem, by dyskurs związany ze szkolną edukacją prawną, zwłaszcza dyskurs podręcznikowy, nie ograniczał się do jednej lub dwóch koncepcji prawnych, stawiając je dodatkowo w opozycji lub zniekształcając, ale wprowadzał różne perspektywy ujmowania prawa. Nie chodzi mi przy tym o to, by podręczniki wskazywały, czym jest np. realizm prawniczy, nurt Law and Society, czy ruch Critical Legal Studies, ale nieco szerzej ujmowały prawo, wskazując np. na wątki kulturalistyczne, krytyczne, pragmatyczne i nie rezygnując z tych, które są już obecne. Odpowiedzi na pytania - „Czym jest prawo?”, „Kto je tworzy?”, „Dla kogo?”, „W jakim celu?”, „Jakie ono jest?” - powinny wykraczać poza perspektywę formalistyczną. Przesunięcie punktu ciężkości z prawa definiowanego czysto formalnie na rozumienie prawa jako zjawiska w szerszym kontekście, uwzględniającego wiele równoważnych perspektyw, jest ważnym krokiem w kierunku zaistnienie lub zwiększenia partycypacji publicznej w procesach tworzenia, zmieniania i rozwijania prawa. Jeżeli postulat partycypacji publicznej, leżący u podstaw edukacji obywatelskiej, nie ma wyłącznie (jak to oceniał Biesta) charakteru politycznego i ma być realizowany we wszystkich obszarach edukacji obywatelskiej, w tym także w ramach szkolnej edukacji prawnej, warto byłoby przebić się przez „zasieki’, które to utrudniają. Przekonanie o znaczeniu i sensie współuczestnictwa w procesach tworzenia prawa, nie mówiąc już o tworzeniu narzędzi i technik pozwalających na takie bezpośrednie uczestnictwo (zwłaszcza na poziomach; lokalnym, wewnątrzinstytucjonalnym, wewnątrzorganizacyjnym), nie pojawi się/nie rozwinie/nie nabierze rozpędu, jeżeli prawo będzie pojmowane w sposób zdepersonalizowany, jako coś nadawanego „odgórnie” i przeznaczonego jedynie „do realizacji”.

\section{Bibliografia}

Biesta G. (2009), What Kind of Citizenship for European Higher Education? Beyond the Competent Active Citizen, „European Educational Research Journal”, Vol. 8, No. 2, Pobrane z: http://dx.doi.org/10.2304/eerj.2009.8.2.146, dostęp: 10.11.2013.

Chojnicka K., Olszewski H. (2004), Historia doktryn politycznych i prawnych. Podręcznik akademicki, Przedsiębiorstwo Wydawnicze Ars boni et aequi, Poznań. 
Czarnota A. (2006), Dwa wymiary postkomunistycznej transformacji i panowania (złego) prawa. Esej na pograniczu socjologii i teorii prawa, [w:] A. Jamróz, S. Bożyk (red.), $Z$ zagadnień współczesnych społeczeństwa demokratycznych, Temida2, Białystok.

Czerepaniak-Walczak M. (1994), Między dostosowaniem a zmianq. Elementy emancypacyjnej teorii edukacji, Wydawnictwo Naukowe Uniwersytetu Szczecińskiego, Szczecin.

Dahlberg G., Moss P., Pence A. (2013), Poza dyskursem jakości w instytucjach wczesnej edukacji i opieki, tłum. K. Gawlicz, Wydawnictwo Naukowe Dolnośląskiej Szkoły Wyższej, Wrocław.

De Cilla R., Reisigl M., Wodak R. (1999), The Discursive Construction of National Identities, "Discourse \& Society" 10:149, pobrane z http://das.sagepub.com/content/10/2/149, dostęp: 10.11.2013.

Friedman L. M. (1993), Republika wyboru. Prawo, autorytet, kultura, thum. W. Madej, Verba, Warszawa.

Giroux H. A. (1983), Theory and Resistance in Education. A Pedagogy for the Oposition, Bergin \& Garvey Publishers Inc., Massachusetts 1983 - rozdz. V - fragmenty wybrane przez Z. Kwiecińskiego, pt. Teoria krytyczna i racjonalność obywatelska, [w:] H. A. Giroux, L. Witkowski (red.), Edukacja i sfera publiczna. Idee i doświadczenia pedagogiki radykalnej, tłum. P. Kwieciński i A. Nalaskowski, Oficyna Wydawnicza Impuls, Kraków 2010.

Geertz C. (2005), Wiedza lokalna. Dalsze eseje z zakresu antropologii interpretatywnej, thum. D. Wolska, Wydawnictwo Uniwersytetu Jagiellońskiego, Kraków.

Habermas J. (2002), Teoria działania komunikacyjnego, t. 2, tłum. A. M. Kaniowski, PWN, Warszawa.

Hildebrandt-Wypych D. (2013), Między państwem a rynkiem - spór o dominujaca we wspótczesnym społeczeństwie i szkole wizję obywatelstwa, [w:] V. Kopińska (red.), Edukacja obywatelska. Rekonstrukcje - krytyka - interpretacje, Wydawnictwo Państwowej Wyższej Szkoły Zawodowej, Włocławek.

Kojder A. (1995), Godność i siła prawa. Szkice socjologiczno-prawne, Oficyna Naukowa, Warszawa.

Kopińska V. (2012), Edukacja prawna z perspektywy humanistyczno-krytycznej, „Rocznik Andragogiczny", 2012, s. 188-196.

Kwieciński Z. (1995), Kryzys społeczeństwa wychowujacego (Hipotezy ostrzegawcze. Propozycje naprawy), [w:] Z. Kwieciński, Socjopatologia edukacji, Mazurska Wszechnica Nauczycielska, Olecko.

Lamentowicz W. (1988), Destrukcja normatywności, [w:] Kultura prawna i dysfunkcjonal- 
ność prawa, tom 1, praca zbiorowa, Wydawnictwo Uniwersytetu Warszawskiego - Wydział Prawa i Administracji, Warszawa.

Luke A. (1997), Introduction: Theory and Practice in Critical Discourse Analysis, [w:] L. Saha (ed.), International Encyclopedia of the Sociology of Education, Elsevier Science Ltd. Pobrane z: http://pages.gseis.ucla.edu/faculty/kellner/ed270/Luke/SAHA6. html, dostęp: 16.11.2013.

Reisigl M. (2010), Dyskryminacja w dyskursach, tłum. D. Przepiórkowska, „Tekst i Dyskurs" nr 3. Pobrane z: www.tekst-dyskurs.pl/tid_3.htmll, dostęp: 19.08.2013.

Reisigl M. (2011), Analiza retoryki politycznej, [w:] R. Wodak, M. Krzyżanowski (red.), Jakościowa analiza dyskursu w naukach społecznych, Oficyna Wydawnicza Łośgraf, Warszawa.

Reisigl M., Wodak R. (2001), Discourse and Discrimination. Rhetorics of Racism and Ant-Semitism. Routledge, London.

Skąpska G. (1988), Wplyw regulacji prawnej na ksztaltowanie się dysfunkcjonalnych form kultury prawnej, [w:] Kultura prawna i dysfunkcjonalność prawa, tom 1, praca zbiorowa, Wydawnictwo Uniwersytetu Warszawskiego - Wydział Prawa i Administracji, Warszawa.

Spektrum Partycypacji Publicznej wg International Association for Public Participation. Pobrane z: http://www.iap2.org/, dostęp: 10.05.2010.

Sztompka P. (2006), Zaufanie w erze globalizacji (szkic problematyki), [w:] M. Borucka-Arctowa, T. Biernat, J. Czapska, H. Opałek, A. Rojek, M. Stepień (red.), Prawo - Wtadza-Społeczeństwo-Polityka. Księga jubileuszowa Profesora Krzysztofa Pałeckiego, Wydawnictwo Adam Marszałek, Toruń.

Sztompka P. (2012), Socjologia: analiza społeczeństwa, Wydawnictwo „Znak”, Kraków.

Szubert W. (1983), Uwagi o kulturze prawnej, [w:] Naród - kultura - osobowość. Księga poświęcona Profesorowi Józefowi Chałasińskiemu, praca zbiorowa, Zakład Narodowy im. Ossolińskich/Wydawnictwo Polskiej Akademii Nauk, Wrocław-Warszawa-Kraków-Gdańsk-Lódź.

Tokarczyk R. (2009), Filozofia prawa, Wydawnictwo Lexis Nexis, Warszawa.

Turska A. (1992), Dynamika ładu normatywnego w społeczeństwie posttotalitarnym, [w:] G. Skąpska, J. Czapska, K. Daniel, J. Górski, K. Pałecki (red.), Prawo w zmieniajacym się społeczeństwie. Wydawnictwo Adam Marszałek/UJ, Kraków.

Van Leeuwen T. (1996), The representation of social actors, [w:] C. R. Caldas-Coulthard, M. Coulthard (eds.), Text and Practices. Readings in Critical discourse Analysis, Routledge, London/New York. 
Violetta Kopińska Koncepcja / rozumienie prawa w dyskursach podręczników...

Van Leewuen T. (2005), Introducing Social Semiotics, Routledge, London-New York.

Witkowski L. (2013), Przełom dwoistości w pedagogice polskiej. Historia, teoria, krytyka, Oficyna Wydawnicza „Impuls”, Kraków.

Zalecenie Parlamentu Europejskiego i Rady Unii Europejskiej nr 2006/962/WE z dnia 18 grudnia $2006 \mathrm{r}$. w sprawie kompetencji kluczowych w procesie uczenia się przez całe życie (Dz.U. L 394 z 30.12.2006).

Zamojska E. (2010), Równość w kontekstach edukacyjnych: wybrane aspekty równości w polskich i czeskich podręcznikach szkolnych, Wydawnictwo Naukowe Uniwersytetu im. Adama Mickiewicza, Poznań. 
